\title{
Study of magnesium bioavailability using stable isotopes and the inductively-coupled plasma mass spectrometry technique in the rat: single and double labelling approaches
}

\author{
BY CHARLES COUDRAY ${ }^{1 *}$, DENISE PEPIN ${ }^{2}$, JEAN CLAUDE TRESSOL ${ }^{1}$, \\ JACQUES BELLANGER ${ }^{1}$ AND YVES RAYSSIGUIER ${ }^{1}$
}

${ }^{1}$ Centre de Recherche en Nutrition Humaine d'Auvergne, Laboratoire Maladies Métaboliques et Micronutriments, INRA de Theix/Clermont-Ferrand, 63122 Saint Genès Champanelle, France

${ }^{2}$ Laboratoire d'hydrologie, Institut Louise Blanquet, Faculté de Pharmacie, Université d'Auvergne, 63000 Clermont-Ferrand, France

(Received 2 May 1996 - Revised 13 September 1996 - Accepted 19 September 1996)

The present work aimed to investigate the feasibility of using stable isotopes and inductively-coupled plasma mass spectrometry (ICP/MS) to study Mg absorption in rats. Male Wistar rats, aged 7 weeks and weighing $180 \mathrm{~g}$, were used. They were fed on a semi-purified diet containing $1070 \mathrm{mg}$ $\mathrm{Mg} / \mathrm{kg}$, and had free access to feed and distilled water. In the first experiment, after a $16 \mathrm{~d}$ adaptation period, two doses of enriched ${ }^{25} \mathrm{Mg}$ (6 and $12 \mathrm{mg}$ ) were administered by oral intubation, faeces and urine were collected daily and blood was sampled. Isotope ratios were determined by ICP/MS. 'True' absorption values, using the faecal isotope data, were 0.63 and 0.56 in rats receiving 6 and $12 \mathrm{mg}{ }^{25} \mathrm{Mg}$ respectively, while apparent absorption was 0.50 for two successive periods of metabolic balance studies. Moreover, the oral isotope administration resulted in a measurable isotopic enrichment in plasma within hours which was still detectable on the third day following the isotope administration. In the second experiment, investigating the double labelling technique, similar rats were dosed simultaneously with $5 \mathrm{mg}{ }^{26} \mathrm{Mg}$ orally (premixed with diet) and $0.29 \mathrm{mg}$ ${ }^{25} \mathrm{Mg}$ intravenously. The calculated $\mathrm{Mg}$ true absorption values were very similar when calculated from blood or urine data (0.38) but were lower than that obtained from faecal data (0.50). The possible causes of such an unexpected difference and limits of the double labelling technique for $\mathbf{M g}$ absorption are discussed here. Together these results indicate that although ${ }^{25} \mathrm{Mg}$ and ${ }^{26} \mathrm{Mg}$ isotopes have high natural abundance, the described methodology permits meaningful investigations of $\mathbf{M g}$ bioavailability and metabolism.

Magnesium: Absorption: Stable isotopes: Inductively-coupled plasma mass spectrometry

Mg plays an essential role in a wide range of fundamental biological and cellular functions and it is not surprising that $\mathrm{Mg}$ deficiency may lead to serious biochemical and symptomatic changes (Durlach, 1988; Rayssiguier et al. 1993a). Recent studies indicate an important role of $\mathrm{Mg}$ deficiency in the aetiology of cardiovascular pathology (Rayssiguier $e t$ al. 1993b; Gueux et al. 1995). Such Mg deficiency may result from inadequate intake and/or impaired intestinal absorption of $\mathrm{Mg}$. An extensive recent review (Hardwick et al. $1990 a$ ) discussed the intestinal sites of $\mathrm{Mg}$ absorption and it was the consensus that the primary site of $\mathrm{Mg}$ absorption is the distal intestine, the ileum (Phillips et al. 1991). However, little information about $\mathrm{Mg}$ absorption and metabolism is available. This lack of data is largely due to restrictions in the use of radioisotopes and methodological problems 
inherent in balance studies (Mertz, 1987). A short half-life has so far limited in vivo use of

${ }^{28} \mathrm{Mg}$. Moreover, absorption studies involving human subjects raise ethical questions regarding the use of radioisotopes. The relatively recent use of stable isotopes in nutrition research offers a safer alternative (Janghorbani \& Ting, 1990; Yergey, 1996). The measurement of absorption based on this methodology requires that accurate isotopic determinations be carried out for the stable isotopes ${ }^{24} \mathrm{Mg},{ }^{25} \mathrm{Mg}$, and ${ }^{26} \mathrm{Mg}$. These measurements have previously been performed by expensive and time-consuming neutron activation or different mass spectrometry techniques (Schwartz \& Giesecke, 1979; Liu et al. 1989; Stegmann \& Karbach, 1993). The recent availability of inductively coupled plasma mass spectrometry (ICP/MS) has indicated the potential for a new and reliable method for conducting mineral bioavailability studies (Schuette et al. 1988; Sandström et al. 1993; Vanhoe, 1993; Crews et al. 1994). It offers high sensitivity, rapid throughput and simple sample preparation. This technique may be useful to study a large number of nutritional and antinutritional factors with true potential to affect $\mathbf{M g}$ absorption. So far, only a few human $\mathrm{Mg}$ absorption studies have been performed with stable isotopes and ICP/MS (Cary et al. 1990; Schuette et al. 1990, 1994; Benech \& Grognet, 1995). However, because of their high cost these studies have often used small numbers of individuals. We propose, therefore, to validate this approach using experimental animal models which, to our knowledge, has not yet been done. This should facilitate its use to study a large number of nutritional absorption factors. Accordingly, we have investigated the feasibility of studying $\mathrm{Mg}$ absorption using single and double labelling techniques with $\mathrm{Mg}$ stable isotopes in rats and compared the results with those determined using metabolic balance techniques.

\section{MATERIALS AND METHODS}

\section{Materials and reagents}

Enriched $\mathrm{Mg}$ isotopes $\left({ }^{25} \mathrm{Mg}\right.$ and ${ }^{26} \mathrm{Mg}$ ) as $\mathrm{MgO}$ were obtained from Chemgas, Boulogne, France. $\mathrm{HNO}_{3}$ (ultrapure), $\mathrm{Mg}$ and $\mathrm{Be}$ standard solutions $(1 \mathrm{~g} / \mathrm{l})$ were obtained from Merck, Darmstadt, Germany. All other chemicals were of the highest quality available. Distilled water was used throughout. A Plasmaquad II system (Fisons Instruments, Manchester) with a Meinhard nebulizer was used for isotopic measurement and a Perkin Elmer 560 (Perkin Elmer, St-Quentin en Yvelines, France) was used for total Mg measurement.

\section{Animals and diet}

Male Wistar rats, aged about 7 weeks, weighing 180 (SE 2.5) g, were used. They were derived from the colony of laboratory animals of the Institut National de la Recherche Agronomique (INRA of Clermont-Ferrand/Theix, France). The rats were housed under conditions of constant temperature $\left(20-22^{\circ}\right)$, humidity $(45-50 \%)$ and a standard dark cycle (20.00-08.00 hours). They received human care in compliance with the guidelines formulated by the European Community for the use of experimental animals (L358$86 / 609 / \mathrm{EEC}$ ). Animals first went through an adaptation period of $16 \mathrm{~d}$ during which they received ad libitum a semi-purified diet containing $1070 \mathrm{mg} \mathrm{Mg} / \mathrm{kg}$ and distilled water. The semi-purified diet contained $(\mathrm{g} / \mathrm{kg})$ : casein 200 , starch 650 , maize oil 50 , fibre 50 , AIN-76 mineral mixture (American Institute of Nutrition, 1977) including MgO 35, AIN76A vitamin mixture (American Institute of Nutrition, 1977) 10, DL-methionine 3, choline 
bitartrate 2. Powder diet $(100 \mathrm{~g})$ was made up with $100 \mathrm{ml}$ distilled water to form a kind of semi-liquid food prepared on site.

\section{Expt 1: single labelling and comparison with balance method}

Stable isotope administration. The isotopic analysis of ${ }^{25} \mathrm{Mg}$ as $\mathrm{MgO}$ yielded the following atom percent figures: ${ }^{24} \mathrm{Mg} 0.95 \%,{ }^{25} \mathrm{Mg} 98.82 \%,{ }^{26} \mathrm{Mg} \mathrm{0.23 \%} .{ }^{25} \mathrm{Mg}(100 \mathrm{mg})$ as oxide was first moistened with $1 \mathrm{ml}$ distilled water, and then $1 \mathrm{ml} 12 \mathrm{M}-\mathrm{HCl}$ (ultrapure) was added to transform the oxide into the soluble chloride of $\mathrm{Mg}$. The solution was then diluted with $18 \mathrm{ml}$ distilled water and adjusted to $\mathrm{pH} 6$ with powdered $\mathrm{NaHCO}_{3}$. Ten rats were divided into two groups of five animals each. On day 0 , at 08.00 hours the animals in group 1 received $6 \mathrm{mg}^{25} \mathrm{Mg}$ and the animals in group 2 received $12 \mathrm{mg}{ }^{25} \mathrm{Mg}(1.2$ or $2.4 \mathrm{ml} \mathrm{Mg}$ solution) by oral administration in the postabsorptive state.

Collection of samples. The faeces and urine of each rat for each day (before and for $6 \mathrm{~d}$ after isotope administration) were collected quantitatively. Animals were lightly anaesthetized by exposure to diethyl ether and blood was sampled from the retro bulbar sinus before and at $0,4,8,12 \mathrm{~h}$ and 1,3 , and $6 \mathrm{~d}$ after stable-isotope administration.

Metabolic balance study periods. Two successive $6 \mathrm{~d}$ balance periods were performed, one before and another after the administration of stable isotope. Daily $\mathrm{Mg}$ intake was determined and the faeces and urine of each rat were quantitatively collected.

\section{Expt 2: double labelling method}

Stable-isotope administration. The isotopic analysis of ${ }^{26} \mathrm{Mg}$ as $\mathrm{MgO}$ yielded the following atom percent figures: ${ }^{24} \mathrm{Mg} 0.41 \%,{ }^{25} \mathrm{Mg} 0.18 \%,{ }^{26} \mathrm{Mg} 99.41 \% .{ }^{26} \mathrm{Mg}(100 \mathrm{mg})$ as oxide was dissolved as indicated earlier for ${ }^{25} \mathrm{Mg}$ isotope. The ${ }^{25} \mathrm{Mg}$ solution, designed for intravenous injection in this experiment, was rendered isotonic by adding a sufficient quantity of $\mathrm{NaCl}$ to a final concentration of $9 \mathrm{~g} / \mathrm{l}$. On the evening of day $-1,5 \mathrm{ml}$ diluted ${ }^{26} \mathrm{Mg}$ isotope solution $(1 \mathrm{mg} / \mathrm{ml}$ ) was mixed with $5 \mathrm{~g}$ diet without $\mathrm{Mg}$. The oral dose was then allowed to equilibrate overnight before being administered. On day 0 , at 08.00 hours, ten fasted animals received their meal diet containing the ${ }^{26} \mathrm{Mg}$ isotope over $2 \mathrm{~h}$ in the dark. The remaining diet was weighed and the exact amount of ${ }^{26} \mathrm{Mg}$ isotope ingested by each animal was determined. At 10.00 hours, animals received $0.25 \mathrm{ml}{ }^{25} \mathrm{Mg}(1.15 \mathrm{mg} / \mathrm{ml})$ intravenously. The dark cycle in this experiment was $22.00-10.00$ hours and the rats therefore received their labelled meal in the dark.

Collection of samples. Faeces and urine of each rat were collected before isotope administration (baseline), and then $12 \mathrm{~h}$ collections were made quantitatively during the first $2 \mathrm{~d}$ and daily for the next $3 \mathrm{~d}$ after isotope administration. Animals were lightly anaesthetized by exposure to diethyl ether and blood was sampled from the retro bulbar sinus before and at day 2 after stable-isotope administration.

\section{Sample treatment and analysis}

Erythrocytes were separated from plasma by centrifugation, washed twice with saline, $(9 \mathrm{~g} \mathrm{NaCl} / 1)$ solution and then lysed into ten volumes of distilled water. Urine volume was determined and $10 \mathrm{ml}$ urine was sampled and acidified with $100 \mu \mathrm{l} 16 \mathrm{M}-\mathrm{HNO}_{3} . \mathrm{Mg}$ concentration and isotope ratios in plasma and urine were determined by ICP/MS after appropriate dilution with $0.16 \mathrm{M}-\mathrm{HNO}_{3}$ using $\mathrm{Be}$ as internal standard. Lysed erythrocytes were first dried overnight and then ashed at $500^{\circ}$ for $10 \mathrm{~h}$. The ash was dissolved in $0.2 \mathrm{ml}$ 
$16 \mathrm{M}-\mathrm{HNO}_{3}$ and $9.2 \mathrm{ml}$ distilled water. The faeces were freeze-dried, powdered and then ashed at $500^{\circ}$ for $10 \mathrm{~h}$. The ash was dissolved in $0.2 \mathrm{ml} 16 \mathrm{M}-\mathrm{HNO}_{3}$ and $9.2 \mathrm{ml}$ distilled water. In each case an appropriate dilution with $0.16 \mathrm{M}-\mathrm{HNO}_{3}$ was performed before the $\mathrm{ICP} / \mathrm{MS}$ analysis. Mg concentration and isotope ratios were determined by ICP/MS. The mass spectrometer settings and plasma conditions were optimized with a solution of $10 \mu \mathrm{g} \mathrm{In} / \mathrm{l}$ and the instrument operating conditions were as follows: radio frequency (RF) generator $27.12 \mathrm{MHz}$, forward $\mathrm{RF}$ power $1350 \mathrm{~W}$, reflected $\mathrm{RF}$ power $<3 \mathrm{~W}$, outer $\mathrm{Ar}$ flow rate 14 litres $/ \mathrm{min}$, intermediate Ar flow rate 0.7 litres $/ \mathrm{min}$, nebulizer Ar flow rate 0.76 litres/min, mass resolution $0.9 \mathrm{Da}$, at $10 \%$ of peak height. Data collection variables were as follows: total replicates per integration 5, signal integration time per replicate $40 \mathrm{~s}$, dwell time per sweep $20.4 \mathrm{~ms}$, scanning mode: peak hopping, five point per peak, sample uptake rate $0.6 \mathrm{ml} / \mathrm{min}$. Total $\mathrm{Mg}$ was determined by flame atomic absorption spectrometry (Perkin Elmer 560).

\section{Calculations}

$\mathrm{Mg}$ has three stable isotopes with the following natural abundance: ${ }^{24} \mathrm{Mg} 78.90 \%,{ }^{25} \mathrm{Mg}$ $10.00 \%$ and ${ }^{26} \mathrm{Mg} 11.10 \%$ (De Bièvre \& Taylor, 1993). Isotopic percent enrichment was obtained from the following equation:

$$
\begin{gathered}
\left(\left({ }^{25} \mathrm{Mg}:{ }^{24} \mathrm{Mg} \text { measured ratio }-{ }^{25} \mathrm{Mg}:{ }^{24} \mathrm{Mg} \text { baseline ratio }\right) /\right. \\
\left.\left({ }^{25} \mathrm{Mg}:{ }^{24} \mathrm{Mg} \text { baseline ratio }\right)\right) \times 100,
\end{gathered}
$$

given that isotopic natural baseline ratios are as follows:

$$
\begin{array}{r}
{ }^{25} \mathrm{Mg}:{ }^{24} \mathrm{Mg} 0 \cdot 1267 \\
\text { and }{ }^{26} \mathrm{Mg}:{ }^{24} \mathrm{Mg} 0 \cdot 1407 \text {. }
\end{array}
$$

The calculation of non-absorbed ${ }^{25} \mathrm{Mg}$ isotope present in the faecal sample (coming only from the label ${ }^{25} \mathrm{Mg}$ isotope) was made as follows:

(total faecal $\mathrm{Mg} \times\left({ }^{25} \mathrm{Mg}:{ }^{24} \mathrm{Mg}\right.$ sample ratio $-{ }^{25} \mathrm{Mg}:{ }^{24} \mathrm{Mg}$ baseline ratio))/ $\left(1.267+\left({ }^{25} \mathrm{Mg}:{ }^{24} \mathrm{Mg}\right.\right.$ sample ratio $-{ }^{25} \mathrm{Mg}:{ }^{24} \mathrm{Mg}$ baseline ratio $\left.)\right)$,

where total faecal $\mathrm{Mg}(\mathrm{mg})$ is determined by atomic absorption spectrometry, and 1.267 is the result of $1 / 0.789$ to convert ${ }^{24} \mathrm{Mg}$ faecal quantity to total faecal $\mathrm{Mg}$. The calculation can also be made directly from ICP/MS data. The two modes of calculation give the same results when the ICP/MS quantitative procedure is used.

The apparent absorption was calculated according to the following equation:

$\mathrm{Mg}$ apparent absorption $(\mathrm{MgAA})=((\mathrm{Mg}$ intake - faecal $\mathrm{Mg}) /(\mathrm{Mg}$ intake $))$,

whereas balance was determined as follows:

balance $(\mathrm{mg} \mathrm{Mg} / \mathrm{d})=$ daily $\mathrm{Mg}$ intake - (daily faecal $\mathrm{Mg}$ + daily urinary $\mathrm{Mg}$ ).

On the same basis, $\mathrm{Mg}$ 'true' absorption, based on faecal isotopic enrichment (single labelling method), was calculated from the following formula:

((administered ${ }^{25} \mathrm{Mg}$ - non-absorbed ${ }^{25} \mathrm{Mg}$ excreted in the faeces)/(administered ${ }^{25} \mathrm{Mg}$ )).

Mg true absorption, derived from blood or urine data (double labelling method) was calculated according to the formula of Yergey et al. (1987):

$\left({ }^{26} \mathrm{Mg}\right.$ nat $\times$ i.v. ${ }^{25} \mathrm{Mg}$ dose $\times$ enrich $\left.{ }^{26} \mathrm{Mg}\right) /\left({ }^{25} \mathrm{Mg}\right.$ nat $\times$ oral ${ }^{26} \mathrm{Mg}$ dose $\times$ enrich $\left.{ }^{25} \mathrm{Mg}\right)$, 
where nat is the ratio of the two isotopes in nature, i.v. ${ }^{25} \mathrm{Mg}$ and oral ${ }^{26} \mathrm{Mg}$ refer to the exact dose given intravenously or orally, and enrich ${ }^{25} \mathrm{Mg}$ or ${ }^{26} \mathrm{Mg}$ represents the degree to which a particular ratio differs from natural levels (isotopic enrichment percentage) at $48 \mathrm{~h}$ after isotope administration.

Endogenous faecal $\mathrm{Mg}$ was calculated as follows (mg/d):

(daily $\mathrm{Mg}$ intake - (daily $\mathrm{Mg}$ intake $\times$ apparent absorption)) - (daily $\mathrm{Mg}$ intake (daily $\mathrm{Mg}$ intake $\times$ true absorption)).

Or simply:

endogenous faecal $\mathrm{Mg}(\mathrm{mg} / \mathrm{d})=$ daily $\mathrm{Mg}$ intake $\times$ (true absorption - apparent absorption).

\section{Statistical analysis}

Throughout the present study, results are expressed as means with their standard errors (SE). The statistical significance of differences $(P<0.05)$ between means was calculated by use of Student's $t$ test.

\section{RESULTS}

\section{Expt 1: single labelling experiment}

$\mathrm{Mg}$ 'true' absorption was calculated from the faecal isotopic enrichment and total nonabsorbed ${ }^{25} \mathrm{Mg}$ isotope. The isotope ratio measurements were performed on an ICP/MS instrument which permitted within- and between-run \% residual standard deviations as follows: $\left({ }^{25} \mathrm{Mg}:{ }^{24} \mathrm{Mg} \mathrm{0.34 \% ,0.81 \% );}{ }^{26} \mathrm{Mg}:{ }^{24} \mathrm{Mg} \mathrm{0.40 \% ,0.94 \% )} \mathrm{respectively.} \mathrm{Table} 1\right.$ shows the faecal isotope enrichment and the cumulative excretion of ${ }^{25} \mathrm{Mg}$ in faeces. The two doses used (6 and $12 \mathrm{mg}$ ) led to considerable enrichment of ${ }^{25} \mathrm{Mg}$ in faecal samples. The majority of faecal non-absorbed ${ }^{25} \mathrm{Mg}(>85 \%)$ was excreted within $24 \mathrm{~h}$ of isotope administration in the rat group receiving $6 \mathrm{mg}{ }^{25} \mathrm{Mg}$ isotope. 'True' absorption values calculated on the basis of faecal non-absorbed ${ }^{25} \mathrm{Mg}$ during the first $3 \mathrm{~d}$ were 0.63 (SE 0.036 ) and 0.56 (SE 0.049 ), and during the totality of the experiment (6d) were 0.63 (SE 0.035 ) and 0.54 (SE 0.049) in rats receiving 6 and $12 \mathrm{mg}{ }^{25} \mathrm{Mg}$ respectively.

Metabolic balance studies. Two successive balance periods were investigated. The results, shown in Table 2, indicate that the apparent absorption of $\mathrm{Mg}$ obtained from the two balance periods was 0.50 , and that the $\mathrm{Mg}$ balance was $+7 \mathrm{mg}$ in both periods.

Endogenous faecal magnesium. The calculation takes into account the daily intake of $\mathrm{Mg}$, the apparent and 'true' absorption as indicated above. The calculated endogenous faecal $\mathrm{Mg}$ varied from 0.44 to $4.08 \mathrm{mg} / \mathrm{d}$ with a mean of $2.53 \mathrm{mg} / \mathrm{d}$, or from $2 \%$ to $18 \%$ with a mean of $11.5 \%$ daily $\mathrm{Mg}$ intake in the rat group receiving $6 \mathrm{mg}{ }^{25} \mathrm{Mg}$ isotope. The rat group receiving $12 \mathrm{mg}{ }^{25} \mathrm{Mg}$ isotope showed similar results $(2.35$ (SE 0.72$) \mathrm{mg} / \mathrm{d}$ and 10.6 (SE 3.50) \% daily Mg intake). Taking the results of both groups, the endogenous faecal $\mathrm{Mg}$ in the present study was 2.44 (SE 0.49) $\mathrm{mg} / \mathrm{d}$ and represented 11.02 (SE 2.29) \% daily Mg intake.

Plasma and urine isotopic enrichments. Fig. 1 shows the appearance and disappearance of administered ${ }^{25} \mathrm{Mg}$ in the plasma and urine in the two groups of rats receiving 6 or $12 \mathrm{mg}{ }^{25} \mathrm{Mg}$. The highest isotopic enrichment in plasma ${ }^{25} \mathrm{Mg}$ was observed after approximately $4 \mathrm{~h}^{25} \mathrm{Mg}$ administration, reaching $84 \%$ and $144 \%$ enrichment in rats 
Table 1. Cumulative faecal ${ }^{25} \mathrm{Mg}$ excretion and percentage isotopic enrichment, and 'true' magnesium absorption in rats*

(Mean values with their standard errors for four rats)

\begin{tabular}{|c|c|c|c|c|c|c|c|c|c|c|c|c|}
\hline \multirow[b]{3}{*}{ Time (h) } & \multicolumn{6}{|c|}{ Rat receiving $6 \mathrm{mg} \dagger$ enriched ${ }^{25} \mathrm{Mg} \ddagger$} & \multicolumn{6}{|c|}{ Rats receiving $12 \mathrm{mg}$ enriched ${ }^{25} \mathrm{Mg} \ddagger$} \\
\hline & \multicolumn{2}{|c|}{$\begin{array}{c}\text { Faecal } \\
\text { enrichment (\%) }\end{array}$} & \multicolumn{2}{|c|}{$\begin{array}{c}\text { Faecal } \\
\text { excretion } \\
(\mu \mathrm{g})\end{array}$} & \multicolumn{2}{|c|}{$\begin{array}{c}\text { 'True' } \\
\text { absorption§ }\end{array}$} & \multicolumn{2}{|c|}{$\begin{array}{c}\text { Faecal } \\
\text { enrichment (\%) }\end{array}$} & \multicolumn{2}{|c|}{$\begin{array}{c}\text { Faecal } \\
\text { excretion } \\
(\mu \mathrm{g})\end{array}$} & \multicolumn{2}{|c|}{$\begin{array}{c}\text { 'True' } \\
\text { absorption§ }\end{array}$} \\
\hline & Mean & SE & Mean & $\mathrm{SE}$ & Mean & SE & Mean & SE & Mean & $\mathrm{SE}$ & Mean & SE \\
\hline $0-24$ & 136 & 17.6 & 1943 & 194 & 0.67 & 0.03 & 291 & 27.8 & 3254 & 959 & 0.69 & 0.08 \\
\hline $24-48$ & 44.4 & 16.2 & 2080 & 226 & 0.65 & 0.04 & 135 & 38.1 & 4723 & 599 & 0.58 & 0.05 \\
\hline $48-72$ & $7 \cdot 25$ & 1.08 & 2169 & 215 & 0.63 & 0.04 & 15.8 & 3.46 & 4923 & 585 & 0.56 & 0.05 \\
\hline $72-96$ & $2 \cdot 58$ & 0.72 & 2197 & 207 & 0.63 & 0.04 & 7.95 & 0.68 & 5014 & 594 & 0.55 & 0.05 \\
\hline $96-120$ & 1.88 & 0.69 & 2213 & 207 & 0.63 & 0.04 & 6.00 & 1.23 & 5076 & 585 & 0.55 & 0.05 \\
\hline $120-144$ & 0.98 & 0.41 & 2223 & 207 & 0.63 & 0.04 & $2 \cdot 50$ & 0.43 & 5432 & 577 & 0.54 & 0.05 \\
\hline
\end{tabular}

* For details of procedures, see pp. 958-961.

+ Values of 'true absorption in rats receiving $6 \mathrm{mg}^{25} \mathrm{Mg}$ were not significantly different from those obtained in rats receiving $12 \mathrm{mg}{ }^{25} \mathrm{Mg}(P>0.05)$.

$\ddagger 1 \mathrm{mg}$ enriched ${ }^{25} \mathrm{Mg}$ represents $0.9885 \mathrm{mg}{ }^{25} \mathrm{Mg}$.

$\S \mathrm{Mg}$ 'true' absorption = (ingested ${ }^{25} \mathrm{Mg}-$ faecal non-absorbed $\left.{ }^{25} \mathrm{Mg}\right) /\left(\right.$ ingested $\left.{ }^{25} \mathrm{Mg}\right)$.

Table 2. Magnesium intake, and faecal and urinary excretion of magnesium in two successive metabolic balance periods in rats*

(Mean values with their standard errors for four rats)

\begin{tabular}{|c|c|c|c|c|c|c|c|c|c|c|}
\hline \multirow[b]{2}{*}{ Balance period $\dagger$} & \multicolumn{2}{|c|}{$\begin{array}{l}\text { Mg intake } \\
(\mathrm{mg} / \mathrm{d})\end{array}$} & \multicolumn{2}{|c|}{$\begin{array}{c}\text { Faecal } \mathrm{Mg} \\
\text { excretion } \\
(\mathrm{mg} / \mathrm{d})\end{array}$} & \multicolumn{2}{|c|}{ MgAA } & \multicolumn{2}{|c|}{$\begin{array}{l}\text { Urinary } \mathrm{Mg} \\
\text { excretion } \\
(\mathrm{mg} / \mathrm{d})\end{array}$} & \multicolumn{2}{|c|}{$\begin{array}{c}\text { Mg balance } \\
(\mathrm{mg} / \mathrm{d})\end{array}$} \\
\hline & Mean & SE & Mean & SE & Mean & SE & Mean & $\mathrm{SE}$ & Mean & SE \\
\hline 1 & 21.96 & 0.76 & $10 \cdot 73$ & 0.95 & 0.51 & 0.07 & $4 \cdot 10$ & 0.49 & $+7 \cdot 14$ & 0.61 \\
\hline 2 & 22.62 & 0.56 & 11.51 & 0.63 & 0.49 & 0.02 & $4 \cdot 27$ & 0.24 & +6.83 & 0.35 \\
\hline
\end{tabular}

* For details of procedures, see pp. 958-960.

$\dagger$ There was no significant difference between the two balance periods.

$\ddagger \mathbf{M g}$ apparent absorption = (ingested $\mathbf{M g}$ - faecal non-absorbed $\mathbf{M g}) /($ ingested $\mathbf{M g}$ ).

receiving 6 or $12{ }^{25} \mathrm{Mg}$ respectively. Absorbed ${ }^{25} \mathrm{Mg}$ was rapidly excreted in urine, and the urine highest ${ }^{25} \mathrm{Mg}$ percentage enrichment was in the fraction $0-12 \mathrm{~h}$ after ${ }^{25} \mathrm{Mg}$ administration. Considering the $6 \mathrm{mg} \mathrm{Mg}$ dose, plasma and urine isotopic enrichments at $48 \mathrm{~h}$ after isotope administration should be sufficiently high to permit accurate isotopic ratio determinations $(<15 \%)$.

\section{Expt 2: double labelling experiment}

Calculation of magnesium true absorption. In order to calculate true absorption from blood and urine data, blood was sampled at day 2 and the isotopic enrichments in ${ }^{26} \mathrm{Mg}$ and ${ }^{25} \mathrm{Mg}$ were determined by measuring isotopic ratios and comparing them with those in samples taken before isotope administration (day 0 ). The plasma isotopic enrichment of ${ }^{26} \mathrm{Mg}$ obtained $2 \mathrm{~d}$ after oral administration was about $20 \%$. However, the plasma isotopic enrichment of ${ }^{25} \mathrm{Mg}$ obtained $2 \mathrm{~d}$ after the intravenous administration was only about $4 \%$. 


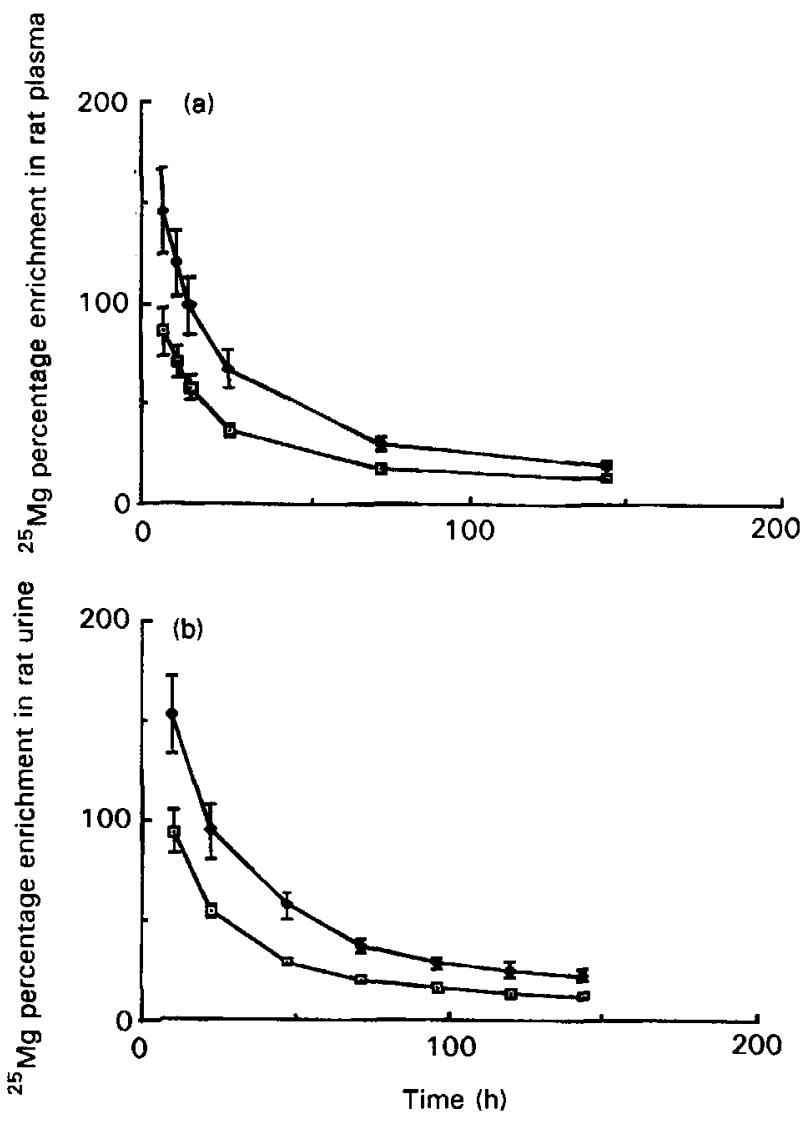

Fig. 1. The appearance and disappearance of administered ${ }^{25} \mathrm{Mg}$ in (a) plasma and (b) urine in two groups of rats receiving $6(\cdot)$ or $12(0){ }^{25} \mathrm{Mg}$. After a $16 \mathrm{~d}$ adaptation period, animals were divided into two groups and received orally either 6 or $12 \mathrm{mg}^{25} \mathrm{Mg}$ isotope. Blood was sampled from the retro bulbar sinus at the indicated times, and urine was collected quantitatively over the entire period of the experiment $(6 \mathrm{~d})$. For further details of procedures, see pp. 958-960. Values are means for four animals, with their standard errors indicated by vertical bars. All values from rats receiving $6 \mathrm{mg}{ }^{25} \mathrm{Mg}$ were significantly different from those obtained in rats with $12 \mathrm{mg}{ }^{25} \mathrm{Mg}$.

Similar isotopic enrichments were observed in erythrocytes obtained $2 \mathrm{~d}$ after isotope administration. As expected, the true absorption values, determined using either the plasma mean 0.38 (SE 0.021 ) or the erythrocyte mean 0.40 (SE 0.053) data, were very similar in the two media (Table 3). Because regular urine collection is easy, the isotopic enrichment was determined on samples of $12 \mathrm{~h}$ up to $48 \mathrm{~h}$ and then on those of $24 \mathrm{~h}$ up to $120 \mathrm{~h}$. As indicated in Table 4, the highest ${ }^{26} \mathrm{Mg}$ enrichment of about $50 \%$ was observed in the first two fractions $(0-12$ and $12-24 \mathrm{~h})$, falling gradually to $8.6 \%$ in the last fraction $(96-120 \mathrm{~h})$. In the $36-48 \mathrm{~h}$ fraction, used to calculate the true absorption, the ${ }^{26} \mathrm{Mg}$ enrichment was $23 \%$, which is slightly higher than that observed in the plasma at $48 \mathrm{~h}$. Concerning the intravenous isotope, the ${ }^{25} \mathrm{Mg}$ enrichment was very high (35.5\%) only in the first fraction $(0-12 \mathrm{~h})$, falling very rapidly to less than $10 \%$ in the next fraction $(12-24 \mathrm{~h})$. In the last fraction (day 5) the ${ }^{25} \mathrm{Mg}$ enrichment was less than $2 \%$. However, in the $36-48 \mathrm{~h}$ urine fraction the ${ }^{25} \mathrm{Mg}$ enrichment was $4.5 \%$, which is also slightly higher than that observed in 
Table 3. ${ }^{25} \mathrm{Mg}$ and ${ }^{26} \mathrm{Mg}$ blood enrichment and magnesium true absorption (MgTA) values calculated $48 \mathrm{~h}$ after isotope administration in individual rats*

\begin{tabular}{lccccccccccc}
\hline \hline Rat... & 1 & 2 & 3 & 4 & 5 & 6 & 8 & 9 & 10 & Mean & SE \\
\hline \hline Plasma & & & & & & & & & & & \\
${ }^{25} \mathrm{Mg}:{ }^{24} \mathrm{Mg}$ enrichment & 2.96 & 4.39 & 3.47 & 3.79 & 3.85 & 3.93 & 3.54 & 3.91 & 3.54 & 3.71 & 0.13 \\
${ }^{26} \mathrm{Mg:}:{ }^{24} \mathrm{Mg}$ enrichment & 21.93 & 30.78 & 16.64 & 19.27 & 15.54 & 15.6 & 18.47 & 13.39 & 16.65 & 18.7 & 1.72 \\
MgTA $\dagger$ & 0.554 & 0.460 & 0.327 & 0.343 & 0.280 & 0.265 & 0.487 & 0.338 & 0.370 & 0.381 & 0.033 \\
Erythrocytes & & & & & & & & & & & \\
${ }^{25} \mathrm{Mg}:{ }^{24} \mathrm{Mg}$ enrichment & 5.19 & 4.03 & 2.86 & 4.95 & $\mathbf{4 . 5 7}$ & 4.51 & 4.48 & 4.22 & 4.79 & 4.40 & 0.23 \\
${ }^{26} \mathrm{Mg}:{ }^{24} \mathrm{Mg}$ enrichment & 23.68 & 30.57 & 17.21 & 21.34 & 16.36 & 25.4 & 36.99 & 17.42 & 16.4 & 22.8 & 2.40 \\
$\mathrm{MgTA} \dagger$ & 0.341 & 0.498 & 0.411 & 0.291 & 0.249 & 0.376 & 0.752 & 0.407 & 0.269 & 0.40 & 0.051 \\
\hline \hline
\end{tabular}

* For details of procedures, see pp. 958-961.

$\dagger \mathrm{MgTA}=\left(\left({ }^{26} \mathrm{Mg}\right.\right.$ nat $\times$ i.v. ${ }^{25} \mathrm{Mg} \times$ enrich $\left.{ }^{26} \mathrm{Mg}\right) /\left({ }^{25} \mathrm{Mg}\right.$ nat $\times$ oral ${ }^{26} \mathrm{Mg} \times$ enrich $\left.\left.{ }^{25} \mathrm{Mg}\right)\right)$, where nat is the ratio of the two isotopes in nature, i.v. ${ }^{25} \mathrm{Mg}$ and oral ${ }^{26} \mathrm{Mg}$ refer to the exact dose given intravenously or orally, and enrich ${ }^{25} \mathrm{Mg}$ or ${ }^{26} \mathrm{Mg}$ represents the degree to which a particular ratio differs from natural levels (isotopic enrichment percentage) at $48 \mathrm{~h}$ after isotope administration.

Table 4. ${ }^{25} \mathrm{Mg}$ and ${ }^{26} \mathrm{Mg}$ urinary excretion, percentage isotopic enrichment and magnesium true absorption (MgTA) in rats $\dagger$

(Mean values with their standard errors for nine rats)

\begin{tabular}{|c|c|c|c|c|c|c|c|c|c|c|}
\hline \multirow{3}{*}{$\begin{array}{l}\text { Time after } \\
\text { isotope } \\
\text { administration (h) }\end{array}$} & \multicolumn{4}{|c|}{ Isotope excretion $(\mu \mathrm{g})$} & \multicolumn{4}{|c|}{ Percentage enrichment } & & \\
\hline & \multicolumn{2}{|c|}{${ }^{25} \mathrm{Mg}$} & \multicolumn{2}{|c|}{${ }^{26} \mathrm{Mg}$} & \multicolumn{2}{|c|}{${ }^{25} \mathrm{Mg}:{ }^{24} \mathrm{Mg}$} & \multicolumn{2}{|c|}{${ }^{26} \mathrm{Mg}:{ }^{24} \mathrm{Mg}$} & \multicolumn{2}{|c|}{ MgTAł } \\
\hline & Mean & SE & Mean & SE & Mean & SE & Mean & SE & Mean & SE \\
\hline $0-12$ & 43.4 & 5.97 & 72.8 & 11.8 & 35.5 & 2.54 & 49.9 & 2.20 & $0.11^{*}$ & 0.09 \\
\hline $12-24$ & 20.8 & 1.23 & 111.8 & $7 \cdot 11$ & 9.91 & 0.44 & $49 \cdot 3$ & 1.19 & 0.37 & 0.01 \\
\hline $24-36$ & 10.5 & 1.08 & 62.9 & 5.17 & $6 \cdot 16$ & 0.19 & $32 \cdot 1$ & 0.95 & 0.39 & 0.02 \\
\hline $36-48$ & 11.3 & 0.50 & 63.6 & 4.93 & 4.56 & 0.21 & 23.0 & 0.77 & 0.38 & 0.02 \\
\hline $48-72$ & 7.82 & 2.00 & 41.6 & 9.43 & 3.30 & 0.20 & 15.5 & 0.44 & 0.36 & 0.02 \\
\hline $72-96$ & 5.81 & 1.48 & 29.1 & 6.62 & 2.29 & 0.14 & 11.0 & 0.51 & 0.37 & 0.02 \\
\hline $96-120$ & 3.42 & 0.72 & $19 \cdot 1$ & 4.06 & 1.73 & 0.14 & 8.55 & 0.35 & 0.38 & 0.02 \\
\hline
\end{tabular}

* Mean values was significantly different from those at all other times, $P<0.05$.

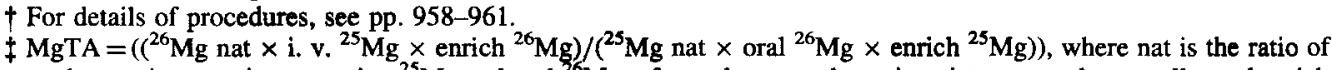
the two isotopes in nature, i.v. ${ }^{25} \mathrm{Mg}$ and oral ${ }^{26} \mathrm{Mg}$ refer to the exact dose given intravenously or orally, and enrich ${ }^{25} \mathrm{Mg}$ or ${ }^{26} \mathrm{Mg}$ represents the degree to which a particular ratio differs from natural levels (isotopic enrichment percentage) at $48 \mathrm{~h}$ after isotope administration.

the plasma at $48 \mathrm{~h}(3.7 \%)$. Table 4 also shows the calculation of true absorption on the different fractions of urine. This confirms that the first urine fraction $(0-12 \mathrm{~h})$ could not be used in the calculation of $\mathrm{Mg}$ true absorption. The calculation of $\mathrm{Mg}$ true absorption from this fraction gives a value of 0.11 , which differs considerably from the other values (means $0 \cdot 36-0.39$ ). As expected, these later values are in agreement with those obtained from blood samples (Table 3). This means that true absorption could be calculated on blood or urine spots $24 \mathrm{~h}$ after isotope administration (Table 4). 
Table 5. ${ }^{25} \mathrm{Mg}$ and ${ }^{26} \mathrm{Mg}$ percentage isotopic enrichment, faecal excretion and 'true' absorption of magnesium ( $M g^{\prime} T A$ ') in rats

(Mean values with their standard errors for nine rats)

\begin{tabular}{|c|c|c|c|c|c|c|c|c|c|c|}
\hline \multirow{3}{*}{$\begin{array}{l}\text { Time after } \\
\text { isotope } \\
\text { administration }(\mathrm{h})\end{array}$} & \multicolumn{4}{|c|}{ Percentage enrichment } & \multirow{2}{*}{\multicolumn{2}{|c|}{$\frac{\text { Isotope excretion }}{{ }^{26} \mathrm{Mg}(\mu \mathrm{g})}$}} & \multirow{2}{*}{\multicolumn{2}{|c|}{$\begin{array}{c}\begin{array}{c}\text { Cumulative } \\
\text { excretion }\end{array} \\
{ }^{26} \mathrm{Mg}(\mu \mathrm{g})\end{array}$}} & \multirow{2}{*}{\multicolumn{2}{|c|}{ Mg'TA' }} \\
\hline & \multicolumn{2}{|c|}{${ }^{25} \mathrm{Mg}:{ }^{24} \mathrm{Mg}$} & \multicolumn{2}{|c|}{${ }^{26} \mathrm{Mg}:{ }^{24} \mathrm{Mg}$} & & & & & & \\
\hline & Mean & SE & Mean & $\mathrm{SE}$ & Mean & SE & Mean & SE & Mean & SE \\
\hline $0-12$ & 0.75 & 0.28 & 98.7 & 44.9 & 454 & 176 & 454 & 176 & $0.90^{*}$ & 0.04 \\
\hline $12-24$ & 2.97 & 0.81 & 430 & 153 & 1036 & 107 & 1491 & 161 & $0 \cdot 66^{*}$ & 0.03 \\
\hline $24-36$ & $1 \cdot 32$ & 0.43 & 60.4 & $11 \cdot 6$ & 460 & $51 \cdot 1$ & 2030 & 153 & 0.56 & 0.03 \\
\hline $36-48$ & 0.67 & 0.16 & $13 \cdot 2$ & 9.21 & 179 & 54.5 & 2077 & 156 & 0.52 & 0.02 \\
\hline $48-72$ & 0.48 & 0.15 & 4.98 & $1 \cdot 18$ & $73 \cdot 1$ & 21.4 & 2150 & 155 & 0.50 & 0.02 \\
\hline $72-96$ & 0.20 & 0.09 & 1.15 & 0.27 & 22.5 & $5 \cdot 36$ & 2173 & 155 & 0.50 & 0.02 \\
\hline $96-120$ & 0.33 & 0.13 & $1 \cdot 17$ & 0.39 & $15 \cdot 3$ & 5.81 & 2188 & 157 & 0.49 & 0.02 \\
\hline $3 \mathrm{~d}$ pool & 1.17 & 0.25 & 58.5 & $6 \cdot 46$ & & & 2143 & 145 & 0.50 & 0.02 \\
\hline $4 \mathrm{~d}$ pool & 0.82 & 0.11 & 39.7 & 2.9 & & & 2164 & 151 & 0.50 & 0.02 \\
\hline
\end{tabular}

* Mean values were significantly different from that at $48-72 \mathrm{~h}, P<0.05$.

$\dagger$ For details of procedures, see pp. 958-961.

$\ddagger \mathrm{Mg}$ 'TA' = (ingested ${ }^{26} \mathrm{Mg}$ - faecal non-absorbed $\left.{ }^{26} \mathrm{Mg}\right) /\left(\right.$ ingested ${ }^{26} \mathrm{Mg}$ ).

Magnesium 'true' absorption. To determine $\mathrm{Mg}$ 'true' absorption derived from the faecal ${ }^{26} \mathrm{Mg}$ isotope data, individual daily faecal samples for each rat were analysed and faecal pools of the first $3 \mathrm{~d}$ after isotope administration were made and analysed. As shown in Table 5, the highest ${ }^{26} \mathrm{Mg}$ enrichment of about $430 \%$ was obtained in the second faecal fraction (12-24h). Moreover, the oral dose of $5 \mathrm{mg}{ }^{26} \mathrm{Mg}$ yielded a faecal isotopic enrichment of $58.5 \%$ in the $3 \mathrm{~d}$ faecal pool (Table 5) and, as expected, the enrichment measured in the 4th day fraction was as low as $1 \%$. This shows clearly that $3 \mathrm{~d}$ collection of faeces is appropriate to determine 'true' absorption of $\mathrm{Mg}$ on the basis of faecal data. When the faecal quantity of non-absorbed ${ }^{26} \mathrm{Mg}$ was determined, the 'true' absorption of $\mathrm{Mg}$ was 0.50 for the $3 \mathrm{~d}$ and $4 \mathrm{~d}$ faecal pools. Table 5 indicates that about $1 \%$ of the nonabsorbed ${ }^{26} \mathrm{Mg}$ was excreted in the faeces on the fourth day after oral ${ }^{26} \mathrm{Mg}$ administration. However, a large part of this faecal ${ }^{26} \mathrm{Mg}$ could come from previously absorbed ${ }^{26} \mathrm{Mg}$ which is re-excreted in the faeces. The results of this experiment show that 'true' absorption based on the faecal excretion of non-absorbed isotope (0.50) can yield a different value from true absorption based on the urine and plasma double labelling technique $(0 \cdot 39)$.

\section{DISCUSSION}

Mechanisms underlying the effects of dietary components on $\mathrm{Mg}$ absorption are generally poorly understood (Brink \& Beynen, 1992). The use of stable isotopes in mineral nutrition research is considered to be an important and valuable tool from the point of view that there is no exposure to radiation and no decay over time. $\mathrm{Mg}$ has three natural stable isotopes: ${ }^{24} \mathrm{Mg}(78.90 \%),{ }^{25} \mathrm{Mg}(10.00 \%)$ and ${ }^{26} \mathrm{Mg}(11.10 \%)$ (De Bièvre \& Taylor, 1993), two of which can be used in bioavailability studies. Although thermal-ionization mass spectrometry (TIMS) is still the reference technique for stable-isotope measurements, inductively coupled Ar plasma mass spectrometry (ICP/MS) has many advantages and could supplant TIMS in many cases (Sandström et al. 1993; Crews et al. 1994). In the 
present work the different methods of determining $\mathrm{Mg}$ absorption were compared, the feasibility of using stable isotopes and the ICP MS technique to study Mg absorption and metabolism was explored, and the appropriate dosage of $\mathrm{Mg}$ isotopes was investigated. To do so, two complementary experiments were conducted in adult rats.

\section{Single labelling and metabolic balance study}

The results of the first experiment show that the mean daily food intake was about $22 \mathrm{~g}$ per rat, which corresponds to about $23 \mathrm{mg} \mathrm{Mg} / \mathrm{d}$. In a classical balance study, the apparent absorption is calculated as $\mathrm{Mg}$ intake minus $\mathrm{Mg}$ faecal excretion and this includes endogenous faecal $\mathrm{Mg}$. The apparent absorption was found to be about 0.50 in both balance periods. Previous work in rats (Brink et al. 1991, 1992; Verbeek et al. 1993) reported similar apparent absorption values for $\mathrm{Mg}$ (0.40-0.60, depending on diet composition). As expected, 'true' absorption of $\mathrm{Mg}(0.64)$, obtained from the faecal non-absorbed isotope measurement, was higher than apparent absorption ( 0.50$)$ by about $15 \%$ when the dosage of ${ }^{25} \mathrm{Mg}$ was $6 \mathrm{mg}$. This difference was expected and is essentially due to the fact that apparent absorption is calculated as intake minus faecal excretion and this includes endogenous faecal $\mathrm{Mg}$. Moreover, the 'true' absorption, obtained here, was nonsignificantly lower in the rats receiving $12 \mathrm{mg}{ }^{25} \mathrm{Mg}$ than in those receiving $6 \mathrm{mg}$ $(P>0.05)$. This slight decrease may be a consequence of a high alimentary level of $\mathrm{Mg}$ (Hardwick et al. 1990a, b; Kayne \& Lee, 1993; Spencer et al. 1994). Schuette et al. (1990) obtained, in infants, a lower true absorption with $60 \mathrm{mg} v .20 \mathrm{mg}{ }^{25} \mathrm{Mg}$ dose. The timecourse of faecal ${ }^{25} \mathrm{Mg}$ excretion, reported in this experiment, showed that more than $75 \%$ of non-absorbed ${ }^{25} \mathrm{Mg}$ was recovered over $24 \mathrm{~h}$ and $99 \%$ of non-absorbed ${ }^{25} \mathrm{Mg}$ was recovered during the first $3 \mathrm{~d}$ from rats receiving $6 \mathrm{mg}{ }^{25} \mathrm{Mg}$. Faecal $\mathrm{Mg}$ is a mixture of non-absorbed $\mathrm{Mg}$ from the diet and non-reabsorbed endogenous excreted $\mathrm{Mg}$. Endogenous faecal $\mathrm{Mg}$ was assessed from the difference between total faecal $\mathrm{Mg}$ (non absorbed $\mathrm{Mg}+$ endogenous $\mathrm{Mg}$ ) calculated from the apparent absorption, and the non-absorbed $\mathrm{Mg}$ calculated from 'true' absorption. Endogenous faecal Mg was mean 2.44 (SE 0.49) $\mathrm{mg}$ daily, which represents $11 \%$ of $\mathrm{Mg}$ daily intake in the present study. Similar measurements in animals were not found in the literature because of the lack of such studies. However, in some human trials, Schwartz et al. (1978) found excretion values of about $25-50 \mathrm{mg} / \mathrm{d}$ or about $10 \%$ of daily $\mathrm{Mg}$ intake in adult man. However, Sojka et al. (1996) found endogenous faecal $\mathrm{Mg}$ of only $12.6 \mathrm{mg}$ or about $5 \%$ of the $250-350 \mathrm{mg} \mathrm{Mg}$ consumed by adolescent girls. In any case, one should bear in mind that these endogenous faecal $\mathrm{Mg}$ estimations are very approximate, because their reliability depends largely on the precision of the apparent and true absorption determinations. Consequently, non-random errors in these later determinations could translate to large variations in endogenous faecal $\mathrm{Mg}$ excretion values (Schuette et al. 1990).

The stable-isotope enrichment in plasma and urine traces the appearance and disappearance of ${ }^{25} \mathrm{Mg}$ in the two rat groups receiving 6 or $12 \mathrm{mg}^{25} \mathrm{Mg}$. These results show that $\mathrm{Mg}$ was rapidly absorbed and its plasma concentration peaked before the fourth hour following isotope administration. This absorbed ${ }^{25} \mathrm{Mg}$ was rapidly eliminated by the kidney. There are only a few studies that have investigated blood levels after oral ingestion of tracer $\mathrm{Mg}$. In the present experiment the highest plasma ${ }^{25} \mathrm{Mg}$ enrichment was observed at about $4 \mathrm{~h}$ reaching $84 \%$ and $144 \%$ in rats receiving 6 or $12 \mathrm{mg}{ }^{25} \mathrm{Mg}$ respectively. Others have also observed a peak of ${ }^{28} \mathrm{Mg} 4 \mathrm{~h}$ after isotope administration in rats (Aikawa, 1981; Hardwick et al. 1990b). The plasma and urine enrichment levels at $24 \mathrm{~h}(35 \%, 54 \%)$ and at $72 \mathrm{~h}(15 \%, 20 \%)$ respectively were sufficiently high to permit accurate isotopic 
measurements and their use to calculate several kinetic constants of $\mathbf{M g}$ metabolism, particularly if used in conjunction with intravenous administration of a second $\mathrm{Mg}$ stable isotope $\left({ }^{26} \mathrm{Mg}\right)$ as in the next experiment.

\section{Double labelling technique}

In the next part of the present work, the double labelling technique was investigated and $\mathrm{Mg}$ absorption was obtained from faecal, urine and blood data. Based on the results of the first experiment, a target dose of $5 \mathrm{mg}^{26} \mathrm{Mg}$ was administered orally and a dose of $0.29 \mathrm{mg}$ ${ }^{25} \mathrm{Mg}$ was injected intravenously. In this second experiment the ${ }^{26} \mathrm{Mg}$ isotope was premixed with $5 \mathrm{~g}$ diet and allowed to equilibrate for $16 \mathrm{~h}$ before administration. To permit rapid consumption, rats were fasted for $16 \mathrm{~h}$ before receiving their labelled meal. The intravenous injection $(0.25 \mathrm{ml})$ was performed immediately after the consumption of the labelled diet (over $2 \mathrm{~h}$ ). The choice of this intravenous dose $\left(0.29 \mathrm{mg}{ }^{25} \mathrm{Mg}\right.$ per rat) was made to ensure sufficiently high isotopic enrichment, and the ${ }^{25} \mathrm{Mg}$ quantity injected in the present experiment was about twice the total plasma $\mathrm{Mg}$ of a rat and thus the maximum that we could administer in a bolus.

It was noted that $48 \mathrm{~h}$ after the intravenous administration of $0.29 \mathrm{mg}{ }^{25} \mathrm{Mg}$ the percentage enrichment in blood and urine was less than $5 \%$. Despite this low enrichment the calculation of true absorption using the formula of Yergey et al. (1987) was still possible because of the good analytical performance of the ICP/MS technique. Moreover, the calculated $\mathrm{Mg}$ true absorption was very similar whatever the biological sample, i.e. plasma, erythrocytes or urine (Table 6). This was to be expected and indicates the robustness of the present methodology. Additionally, the urine data showed that the true absorption could be determined as early as approximately $24 \mathrm{~h}$ after isotope administration where we obtained a higher percentage enrichment than at $48 \mathrm{~h}$, which allowed more accurate isotopic ratio determinations.

In this experiment, the $\mathrm{Mg}$ 'true' absorption obtained from the faecal data was about 0.50 . However, the 'true' absorption obtained from faecal data was considerably higher than that obtained from blood and urinary data $(0 \cdot 38)$. In the double labelling technique it is assumed that there is no difference in the distribution of the two tracers once they have

Table 6. Individual magnesium true absorption values in rats determined using blood and urine samples obtained $48 \mathrm{~h}$ after isotope administration, and using faecal samples collected over $5 d \dagger$

\begin{tabular}{|c|c|c|c|c|c|c|c|c|c|c|c|}
\hline Rat... & 1 & 2 & 3 & 4 & 5 & 6 & 8 & 9 & 10 & Mean & $\mathrm{SE}$ \\
\hline Plasmał & 0.55 & 0.46 & 0.33 & 0.34 & 0.28 & 0.27 & 0.49 & 0.34 & 0.37 & $0.38 *$ & 0.02 \\
\hline Erythrocytef & 0.34 & 0.50 & 0.41 & 0.29 & 0.25 & 0.38 & 0.75 & 0.41 & 0.27 & 0.40 & 0.05 \\
\hline Urineł & 0.41 & $0-48$ & $0 \cdot 35$ & 0.38 & 0.32 & 0.27 & 0.50 & 0.35 & $0 \cdot 30$ & $0.38 *$ & 0.02 \\
\hline Faeces§ & 0.51 & 0.54 & 0.48 & 0.48 & 0.46 & 0.40 & 0.57 & 0.54 & 0.52 & 0.51 & 0.02 \\
\hline
\end{tabular}

* Mean values were significantly different from that obtained from faecal data, $P<0.05$.

+ For details of procedures, see pp. 958-961.

$\ddagger \mathrm{Mg}$ true absorption $=\left(\left({ }^{26} \mathrm{Mg}\right.\right.$ nat $\times$ i.v. ${ }^{25} \mathrm{Mg} \times$ enrich $\left.{ }^{26} \mathrm{Mg}\right) /\left({ }^{25} \mathrm{Mg}\right.$ nat $\times$ oral ${ }^{26} \mathrm{Mg} \times$ enrich $\left.\left.{ }^{25} \mathrm{Mg}\right)\right)$, where nat is the ratio of the two isotopes in nature, i.v. ${ }^{25} \mathrm{Mg}$ and oral ${ }^{26} \mathrm{Mg}$ refer to the exact dose given intravenously or orally and enrich ${ }^{25} \mathrm{Mg}$ or ${ }^{26} \mathrm{Mg}$ represents the degree to which a particular ratio differs from natural levels (isotopic enrichment percentage) at $48 \mathrm{~h}$ after isotope administration.

$\S \mathrm{Mg}$ 'true' absorption = (ingested ${ }^{26} \mathrm{Mg}$ - faecal non-absorbed ${ }^{26} \mathrm{Mg}$ )/(ingested ${ }^{26} \mathrm{Mg}$ ). Data were calculated on the basis of $3 \mathrm{~d}$ collection of faeces. 
entered the circulation by the two routes of administration. In other words, the absorbed portion of the oral ${ }^{26} \mathrm{Mg}$ will be distributed and excreted exactly as the entire intravenous ${ }^{25} \mathrm{Mg}$ dose. However, a large dose of tracer $(0.29 \mathrm{mg})$ was injected which induced a moderate hypermagneseamia responsible for rapid urinary excretion of the ${ }^{25} \mathrm{Mg}$. In fact, it is known that urinary excretion of $\mathrm{Mg}$ plays an important role in the control of $\mathrm{Mg}$ homeostasis (Quamme, 1993). This means that small changes in serum $\mathrm{Mg}$ are accompanied by a rapid increase or decrease in urinary $\mathrm{Mg}$ excretion. Therefore, an important part of intravenously injected ${ }^{25} \mathrm{Mg}$ could be excreted immediately or very rapidly in urine and thus not behave like the absorbed ${ }^{26} \mathrm{Mg}$ isotope. The results obtained in the present study are in agreement with such an hypothesis. In this regard, we noted that only $18 \%$ of the total urinary ${ }^{26} \mathrm{Mg}$ was excreted in the first fraction $(0-12 \mathrm{~h})$, whereas more than $41 \%$ of the total urinary ${ }^{25} \mathrm{Mg}$ was excreted in the first fraction $(0-12)$. Given the high natural abundance of available $\mathrm{Mg}$ isotopes $(10 \%)$, it was necessary to inject a large dose of tracer in comparison with the body pool of $\mathrm{Mg}$. Thus, it is preferable that intravenous $\mathrm{Mg}$ isotope should be given over a long period of time or divided into two or more small successive injections. The likely effect of perturbation of body pools needs further consideration in relation to the results obtained.

Finally, the results of this second experiment also showed a significantly $(P<0.005)$ lower 'true' absorption (0.50) than in the first experiment $(0.63)$, suggesting that administration of ${ }^{26} \mathrm{Mg}$ premixed with the diet could be responsible for a decrease in fractional $\mathrm{Mg}$ absorption in comparison with the results of the first experiment where the ${ }^{25} \mathrm{Mg}$ isotope was given in liquid form by oral administration. This was confirmed in an other study in our own laboratory (Coudray et al. 1996). Schuette et al. 1990 found that $\mathrm{Mg}$ absorption was consistently less after bolus $v$. distributed administration of the same dose of $\mathrm{Mg}$ isotope in infants. Indeed, free ${ }^{25} \mathrm{Mg}$ given in liquid form in the first experiment cannot necessarily be assumed to have distributed in the intestine in a manner similar to ${ }^{26} \mathrm{Mg}$ equilibrated with or $\mathrm{Mg}$ bound in food (Hardwick et al. 1990a).

In conclusion, this work compared apparent absorption with true absorption, and optimized the dosages of $\mathrm{Mg}$ isotopes required in an experimental rat model. $\mathrm{Mg}$ 'true' absorption can be determined by the single labelling technique using ICP/MS and faecal monitoring. In this regard, doses as low as $2-3 \mathrm{mg} \mathrm{Mg}$ isotope $\left({ }^{25} \mathrm{Mg}\right.$ or $\left.{ }^{26} \mathrm{Mg}\right)$ can be sufficient. The advantage of using the double labelling technique is that it does not require faecal collections similar to those performed for mass balance. Because of the high renal regulation of $\mathrm{Mg}$, isotope enrichment calculations should, however, preferably be performed on biological samples $24 \mathrm{~h}$ after isotope administration. However, the rapid urinary elimination of the intravenous tracer may lead to poor estimation of $\mathrm{Mg}$ true absorption. This technique may be more convenient for comparative studies on $\mathbf{M g}$ bioavailability.

The authors would like to thank Dr Fred Mellon (Institute of Food Research, Norwich) for reading the manuscript. We also gratefully acknowledge the enthusiastic co-operation of Elyett Gueux.

\section{REFERENCES}

Aikawa, J. K. (1981). Physiology of magnesium in man. In Magnesium: Its Biological Significance, pp. 43-56 [J. K. Aikawa, editor]. Boca Raton: CRC Press Inc.

American Institute of Nutrition (1977). Report of the American Institute of Nutrition ad hoc committee on standards for nutritional studies. Journal of Nutrition 107, 1340-1348. 
Benech, H. \& Grognet, J. M. (1995). Recent data on the evaluation of magnesium bioavailability in humans. Magnesium Research 8, 277-284.

Brink, E. J. \& Beynen, A. C. (1992). Nutrition and magnesium absorption: a review. Progress in Food and Nutrition Science 16, 125-162.

Brink, E. J., Dekker, P. R., Van Beresteijn, E. C. \& Beynen, A. C. (1991). Inhibitory effect of dietary soybean proteins $v s$ casein on magnesium absorption in rats. Journal of Nutrition 121, 1374-1381.

Brink, E. J., Van den Berg, G. J., Van der Meer, R., Wolterbeek, H. Th., Dekker, P. R. \& Beynen, A. C. (1992). Inhibitory effect of soybean protein $v s$. casein on apparent absorption of magnesium in rats is due to greater excretion of endogenous magnesium. Journal of Nutrition 122, 1910-1916.

Cary, E. E., Wood, R. J. \& Schwartz, R. (1990). Stable Mg isotopes as tracers using ICP/MS. Journal of Micronutrient Analysis 8, 13-22.

Coudray, C., Bousset, C., Pepin, D., Tressol, J. C., Sominar, E. \& Rayssiguier, Y. (1996). Study of magnesium, zinc and copper absorption using stable isotopes and inductively coupled plasma/mass spectrometry technique in the rats. European Academy of Nutritional Sciences meeting, 22-24 August 1996, Copenhagen, Denmark.

Crews, H. M., Ducros, V., Eagles, J., Mellon, F. A., Kastenmayer, P., Luten, J. B. \& McGaw, B. A. (1994). Mass spectrometric methods for studying nutrient mineral and trace element absorption and metabolism in humans using stable isotopes. Analyst 119, 2491-2514.

De Bièvre, P. \& Taylor, P. D. P. (1993). Table of isotopic composition of the elements. Intemational Journal of Mass Spectrometry Ion Process 123, 149-166.

Durlach, J. (editor) (1988). Magnesium in Clinical Practice. London: John Libbey.

Gueux, E., Azais-Braesco, V., Bussière, L., Grolier, P., Mazur, A. \& Rayssiguier, Y. (1995). Effect of magnesium deficiency on triacylglycerol-rich lipoprotein and tissue susceptibility to peroxidation in relation to vitamin E content. British Journal of Nutrition 74, 849-856.

Hardwick, L. L., Jones, M. R., Brautbar, N. \& Lee, D. B. N. (1990a). Site and mechanism of intestinal magnesium absorption. Minerals and Electrolyte Metabolism 16, 174-180.

Hardwick, L. L., Jones, M. R., Buddington, R. K., Clemens, R. A. \& Lee, D. B. (1990b). Comparison of calcium and magnesium absorption, in vivo and in vitro studies. American Journal of Physiology 259, G720-G726.

Janghorbani, M. \& Ting, B. T. G. (1990). Stable isotope methods for studies of mineral/trace element metabolism. Journal of Nutritional Biochemistry 1, 4-19.

Kayne, L. H. \& Lee, D. B. N. (1993). Intestinal magnesium absorption. Minerals and Electrolyte Metabolism 19, 210-217.

Liu, Y. M., Neal, P., Emst, J., Weaver, C., Richard, K., Smith, D. L. \& Lemons, J. (1989). Absorption of calcium and magnesium from fortified human milk by very low birth weight infants. Pediatric Research 25, 496-502.

Mertz, W. (1987). Use and misuse of balance studies. Journal of Nutrition 117, 1811-1813.

Phillips, J. D., Davies, R. J., Keighley, M. R. B. \& Birch, N. J. (1991). Magnesium absorption in human ileum. Journal of American College of Nutrition 10, 200-204.

Quamme, G. A. (1993). Magnesium homeostasis and renal magnesium handling. Mineral Electrolyte Metabolism 19, 218-225.

Rayssiguier, Y., Durlach, J., Gueux, E., Rock, E. \& Mazur, A. (1993a). Magnesium and ageing. I- Experimental data: importance of oxidative damage. Magnesium Research 6, 369-378.

Rayssiguier, Y., Gueux, E., Bussiere, L., Durlach, J. \& Mazur, A. (1993b). Dietary magnesium affects susceptibility of lipoproteins and tissues to peroxidation in rats. Journal of American College of Nutrition 12 , 133-137.

Sandström, B., Fairweather-Tait, S., Hurrell, R. \& Van Dokkum, W. (1993). Methods for studying mineral and trace element absorption in humans using stable isotopes. Nutrition Research Review 6, 71-95.

Schuette, S. A., Lashner, B. A. \& Janghorbani, M. (1994). Bioavailability of magnesium diglycinate vs magnesium oxide in patients with ileal resection. Journal of Parenteral and Enteral Nutrition 18, $430-435$.

Schuette, S., Vereault, D., Ting, B. T.G. \& Janghorbani, M. (1988). Accurate measurement of stable isotopes of magnesium in biological materials with inductively coupled plasma mass spectrometry. Analyst 113, 18371842.

Schuette, S., Ziegler, E. E., Nelson, S. E. \& Janghorbani, M. (1990). Feasibility of using the stable isotope ${ }^{25} \mathrm{Mg}$ to study Mg metabolism in infants. Pediatric Research 27, 36-40.

Schwartz, R. \& Giesecke, C. C. (1979). Mass spectrometry of a volatile Mg chelate in the measurement of stable ${ }^{26} \mathrm{Mg}$ when used as a tracer. Clinica Chimica Acta 97, 1-8.

Schwartz, R., Spencer, H. \& Wentworth, R. A. (1978). Measurement of magnesium absorption in man using stable ${ }^{26} \mathrm{Mg}$ as a tracer. Clinica Chimica Acta 87, 265-273.

Sojka, J., Wastney, M., Abraham, S., Froese, S., Martin, B. \& Weaver, C. (1996). Determination of magnesium kinetics using stable isotope tracers in adolescent girls. FASEB Journal Abstracts 10, A782.

Spencer, H., Fuller, H., Norris, C. \& Williams, D. (1994). Effect of magnesium on the intestinal absorption of calcium in man. Journal of the American College of Nutrition 13, 485-492.

Stegmann, W. \& Karbach, U. (1993). Plasma kinetics of magnesium and calcium stable isotope tracers in a human subject after simultaneous oral ingestion of ${ }^{25} \mathrm{Mg}$ and ${ }^{44} \mathrm{Ca}$ determined by thermal ionisation mass spectrometry. Biological Mass Spectrometry 22, 441-446. 
Vanhoe, H. (1993). A review of the capabilities of ICP/MS for trace analysis in body fluids and tissues. Journal of Trace Element Electrolytes in Health and Disease 7, 131-139.

Verbeek, M. J. F., Van Den Berg, G. J., Lemmens, A. G. \& Beynen, A. C. (1993). High protein intake raises apparent but not true magnesium absorption in rats. Journal of Nutrition 123, 1880-1887.

Yergey, A. (1996). Analytical instruments for stable isotopic tracers in mineral metabolism. Journal of Nutrition 126, 355S-361S.

Yergey, A. L., Vieira, N. E. \& Covell, D. G. (1987). Direct measurement of dietary absorption using calcium isotopic tracers. Biomedical and Environmental Mass Spectrometry 14, 603-607. 